\title{
Entrepreneurship In U.S. Auto Industry: Ford Stays Ahead
}

\author{
Wali I. Mondal, National University, USA
}

\begin{abstract}
The big three U.S. auto manufacturers namely General Motors, Ford and Chrysler play an important role in the U.S. economy. The total direct and indirect employment by these manufacturers account for over 3 million jobs. Combined total sales before the onset of the recession of 2007-09, known as the "Great Recession" was \$412 Billion. More than the employment and income effect, the auto companies with their manufacturing plants, dealership and service organizations dominate the American landscape. The big three auto makers performed well by conventional measurement of their revenues until the Great Recession hit in 2007. The purpose of this paper is to analyze how the revenues of General Motors and Chrysler plunged so deep as to force them file bankruptcy and seek government help in the form of Troubled Assets Relief Program (TARP), and how Ford avoided it with a background of entrepreneurship that dates back to its founder, Henry Ford. Through his pioneering work, Schumpeter analyzed entrepreneurship using the production function approach and identified five factors which an entrepreneur uses for innovation and for changing the existing way of doing business. Schumpeter termed this process as "creative destruction". These five factors are: introduction of a new good; adoption of new inputs to produce a new good or the previously produced good; introduction of new technology; opening of a new market; and creating a new economic organization. The paper uses the five factor model of Schumpeter to analyze entrepreneurship in the U.S. auto industry and demonstrates that the tradition of innovation through new technology and new sources of supply was woven into the corporate structure of Ford Motor Company since it went public in 1956. The analysis shows that while Ford continued in the path of entrepreneurship, its American rivals failed to capture the deep implication of several significant turn of events including the gas crunch of 1979. This allowed Ford to stabilize its base, increase its market share and earn profit in the height of the Great Recession.
\end{abstract}

Keywords: Entrepreneurship; big three; great recession; auto industry; innovation; Schumpeter; creative destruction

\section{INTRODUCTION}

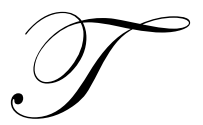

he first car of the world, the four-wheeled De Dion-Bouton et Trepardoux, nicknamed "La Marquise" was built in France in 1884, about a year before Gottlieb Daimler and Karl Benz of Germany built their first experimental gasoline-powered cars. The first mass-produced car was manufactured by Ransom Eli Olds who co-founded the Olds Motor Vehicle Company in August 1897. The first mass-produced car ("Model A" cars) sold in the U.S. was produced by the Ford Motor Company in 1903.

After the introduction of Ford's Model A cars, other automobile manufactures came to the market; however, the U.S. automobile market is dominated by three big producers, often referred to as the "Big Three". These are:

1. Ford Motor founded by Henry Ford and 12 associates in 1903

2. General Motors founded by William "Billy" Durant in 1908

3. Chrysler Motor Company founded by Walter P. Chrysler in 1925 by re-organizing Maxwell Motor Company 
The big three U.S. auto manufacturers play an important role in the U.S. economy. Apart from the employment and income effect, the auto companies with their manufacturing plants, dealership and service organizations dominate the American landscape. In a testimony to the Congress on December 4, 2008, Alan Mulally, President and Chief Executive Officer of Ford, summarized the relationship between American citizens and their auto makers with the following words: "We are woven into the fabric of every community that relies on our cars and trucks and the jobs our company supports" (Mulally, 2008).

The big three auto makers performed well by conventional measurement of their revenues until the "Big Recession" hit in 2007. With the onset of the Big Recession, revenues of two of the big three auto makers plunged so deep as to force them file bankruptcy and seek government help in the form of Troubled Assets Relief Program (TARP). Ford Motors did not need government support and performed remarkably well compared to two of its counterparts, and actually posted a hefty profit after the fourth quarter of 2009. It is the contention of this paper that Ford Motors was able to steer through the Big Recession with a background of entrepreneurship that dates back to its founder, Henry Ford. The paper analyzes entrepreneurship in the auto industry with a particular reference to Ford Motors using the five-factor model of Schumpeter.

\section{THE BIG RECESSION: FORD STANDS OUT}

The Big Three auto maker dominated the U.S. auto industry until the mid 1980s. In 1985, the Big Three's U.S. market share was 85 per cent until they faced strong competition from the Japanese compact and sub-compact auto makers, notably from Toyota and Honda. The landscape of the American automobiles gradually transformed from the Big Three to the Big Five. Figure 1 demonstrates the performance of the Big Three at the height of the Big Recession of 2008-09, from January 2008 to June 2009 along with two leading Japanese auto makers, Toyota and Honda. Remarkably, Ford showed an upward trend compared to its two rivals, General Motors and Chrysler as well as its Japanese competitors. The recession of 2007-2009 had a significant negative impact on the finance and liquidity of the Big Three auto makers. All three were losing revenues prior to the 2007 recession; continually plunging sales forced two of the three to declare bankruptcy and seek government help. On April 30, 2009 Chrysler, the smallest of the Big Three filed for Chapter 11 bankruptcy protection in New York after a group of creditors defied government pressure to wipe out Chrysler's debt. Thirty-one days later on June 1, 2009 General Motors, the largest carmaker for 77 years until 2008, followed Chrysler and filed for bankruptcy. Ford maneuvered through the hard times and neither filed for bankruptcy nor sought federal government protection.

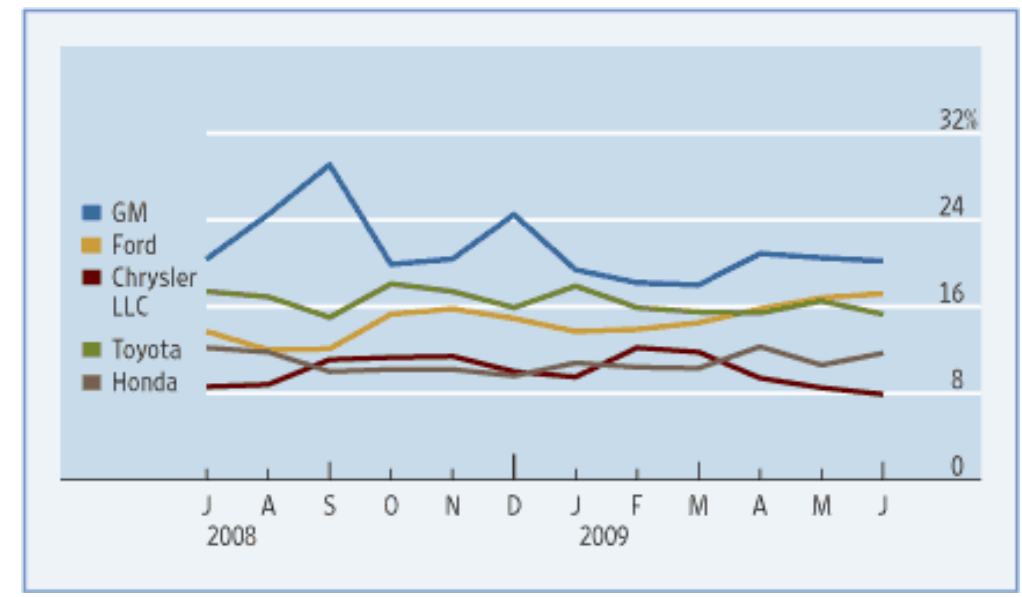

Figure 1: The Big Recession and the Big Five Auto Makers

Source: www.motorintelligence.com adapted from www.wsj.com; July 01, 2009

Ford performed well through the hard times as evidenced by the profits it earned in 2009. While its rivals General Motors and Chrysler both posted hefty losses since filing bankruptcy, Ford Motor Company, whose financial year ends on December 31, posted a profit of \$2.7 Billion. 
(http://www.pe.com/business/local/stories/PE Biz W webonly ford29.3555d28.html). General Motors posted a $\$ 4.3$ billion net loss from the time of its emergence from bankruptcy in July through the end of 2009. http://www.france24.com/en/20100407-gm-posts-billion-dollar-loss-usa-business-automaker-cars-sec Chrysler, which emerged from bankruptcy last June, reported that it lost $\$ 3.8$ billion through the end of the year. http://www.washingtonpost.com/wp-dyn/content/article/2010/04/21/AR2010042100984.html

We trace the remarkable performance of Ford as the entrepreneurial tradition of the company dates back to the days of its founder, Henry Ford.

\section{HENRY FORD THE ENTREPRENEUR}

In June 1903, Henry Ford founded Ford Motor Company in collaboration with twelve other investors who invested a total of $\$ 28,000$ in his company. Ford now began production of the Model A car. The car sold well and the company became one of the most profitable enterprises of the time. By 1907 the profits of Ford Motor Company surpassed one million dollars. During these initial years, Ford experimented with more than one model of cars; however, he soon realized the company would be making more profits if it refined its most popular model with innovative technologies and saved on labor costs. Accordingly, in 1909 Ford took the decision to manufacture only one type of car, the Model T.

The model T car was performing well in the market; however, the entrepreneur, Henry Ford, devised other ways of increasing profits. He found that it initially took 14 hours to assemble a Model T car. This amount of labor time in assembling a car seemed excessive to him and he started devising ways and means of saving the labor time. By improving his methods of large scale production, known at time as the "mass production method", Ford reduced the assembly time to 1 hour 33 minutes. This dramatic reduction of assembly time lowered the overall cost of each car significantly allowing Ford to undercut the price of other cars on the market. In1908 the price of a model T car was $\$ 1,000$. By introducing newer technologies and reducing labor cost substantially, the selling price of a Model T car went down to $\$ 360$ in 1916 (Datamonitor, 2009).

\section{BEHIND FORD'S SUCCESS: A MODEL TO ANALYZE ENTREPRENEURSHIP}

In this section, we analyze entrepreneurship in the U.S. auto industry with particular reference to the Ford Motor Company using Schumpeter's Five-Factor model. Private means of production leads to innovation and assumption of risk. These two phenomena, innovation and risk taking are associated with entrepreneurship. The term "entrepreneur" was first introduced in the Mercantilist age by Richard Cantillon (1680-1734). Schumpeter (1950) noted "Cantillon's work, which is usually, though not quite correctly described as the first systematic treatise on economics, then introduced the term "entrepreneur". Cantillon defined this entrepreneur as the agent who buys means of production at certain prices in order to combine them into a product that he is going to sell at prices that are uncertain at the moment at which he commits himself to his costs". (pp 253-54). The idea thus developed by Cantillon was incorporated into Say's Treatise on Political Economy (1821).

Say defined an entrepreneur as an agent who combines other resources into a "productive organism". He also used the term to indicate shifting of resources from a lower productive state to a higher productive state. It is important to note that Say did not incorporate the element of risk in his analysis of entrepreneurship although Cantillon alluded to it. Later, John Stuart Mill developed the concept further and associated entrepreneurship with activities involving risk and profit (Mill, 1871).

Although Mill incorporated risk in his analysis of profit and linked it to entrepreneurship, he, in fact was using the terms "entrepreneur" and "capitalist" synonymously. It appears that during most of the later nineteenth century, the two terms were used synonymously. Joseph Schumpeter is the first economist who distinguished between an entrepreneur and a capitalist (Schumpeter, 1939, 1950). According to him, assumption of risk involving innovation is the role of the entrepreneur, while assumption of risk involving potential for profit is the role of a capitalist. Both an entrepreneur and a capitalist undertake risk; but their domains are separate. Individuals who own business and take risk with their capital in pursuit of profit, but do not innovate, are capitalists. There are individuals who take risk by introducing a new product, adopting a new production process, creating new markets, introducing 
new technology or creating a new economic organization. Schumpeter referred to these individuals as "entrepreneurs" who belong to a "distinct sociological class". According to him, the process of discovery and innovation modifies the past and creates new opportunities for the creation of wealth in the future. This is what Schumpeter described as the process of "creative destruction".

According to Schumpeter, "the function of entrepreneur is to reform or revolutionize the pattern of production by exploiting an innovation or, more generally, an untried technological possibility for producing a new commodity or producing an old one in a new way, by opening up a new source of supply of materials or a new outlet for products, by reorganizing an industry..." He went on to attribute innovation as the business activity that brings about a new production function as a result of one or more of the following five economic activities:

1. introduction of a new good

2. adoption of new inputs to produce a new good or the previously produced good

3. introduction of new technology

4. $\quad$ opening of a new market; and

5. creating a new economic organization.

Schumpeter's five factors of entrepreneurship revolve around innovation and may be portrayed in the following figure.

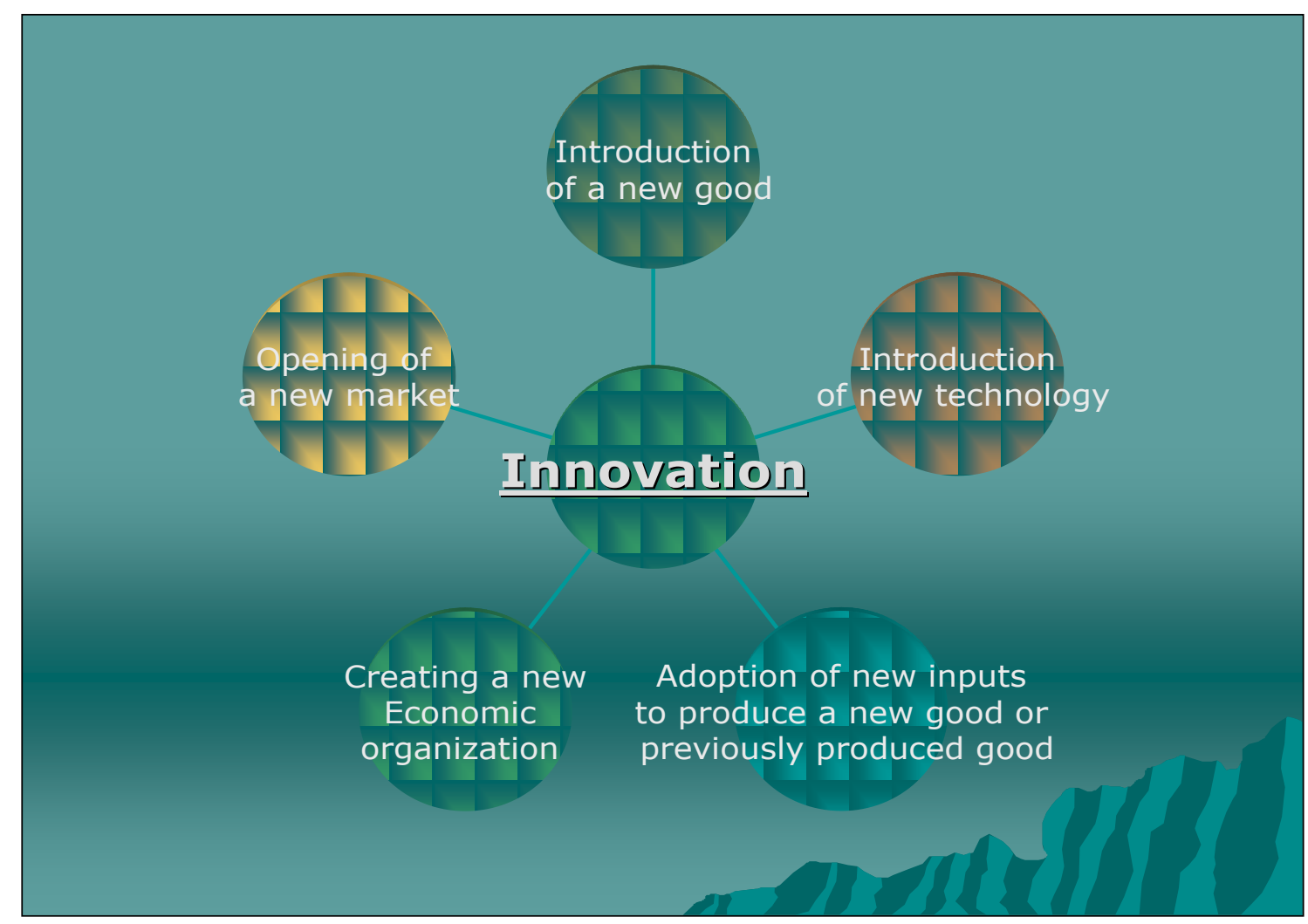

Figure 2: Schumpeter's Five Factor Model of Entrepreneurship

Schumpeter described two different patterns of industrial innovation linked to entrepreneurship. One form of industrial innovation described by Schumpeter in The Theory of Economic Development (1934) is small firms operating in highly competitive industries, while in Capitalism, Socialism and Democracy (1942), this role is played 
by large firms operating in oligopolistic industries. Studies suggest that both Schumpeterian patterns of innovation can co-exist in an economy in different industries (Arrow, 1962; Herbert and Link, 1982).

Schumpeter's theory of entrepreneurship stimulated extensive writing on the subject. Numerous studies have supported various sets of personality characteristics based on certain assumptions about behavior where sets of criteria, traits and personal principles and characteristics provide different types of insight. An approach now gaining more popularity explains entrepreneurship by combining economic, personal, and sociological variables. Personal characteristics, such as the need for achievement, risk-taking propensity, locus of control, beliefs about wealth and material gain, and business growth are related to a person's predisposition toward business leadership (Gartner, 1990, McDaniel, 2002). A belief that a person can influence his personal destiny and locus of control distinguishes entrepreneurs from the general population.

In reality, Schumpeter's model works through the transformation of a production function. A production function is the technological relationship between inputs and outputs. In other words, a production function refers to the methods and processes by which the factors of production namely land, capital and labor are combined by an entrepreneur for tangible output. This is where Schumpeter made a distinction between the terms invention and innovation. According to him, invention is discovery of new ideas, concepts, or material items that are normally confined to speculative reasoning. Such reasoning can be abstract and may remain uninvestigated in a scientific laboratory; however, if an invention in the form of an idea or a material item is transferred to the business sector with a view to changing the production function, then it becomes innovation.

According to Schumpeter, the above five elements of innovation translate to the domain of activities of an entrepreneur. A brief description of entrepreneurial activities related to the above innovations is presented below.

The introduction of a new good: Arguably this is the most important activity of an entrepreneur pertaining to the change in a production function. An entrepreneur seizes the opportunity to introduce a new product in the market that is currently not available to the consumer. In the context of Ford Motor Company, this occurred early in the life of the company when Henry Ford successfully experimented with various models of automobiles. In 1956, Ford went public. In the same decade, Ford produced one of its most successful cars, the Thunderbird. The global expansion of Ford continued during the 1960s when the company established Ford Europe in 1967. Throughout the 1970s and 1980s, Ford continued to expand, with further moves into Europe and Asia. In 1987, Ford helped to form the Park Ridge in order to acquire the Hertz car rental business. Ford experienced further growth in the 1990s. In 1990, Ford acquired Jaguar.The company increased its stake in Hertz to 100\% in 1994.The company acquired the repair chain Kwik-Fit in 1999 and later Volvo's passenger vehicle business. Ford spun off its Visteon automotive components business unit during 2000. Ford also acquired Land Rover from BMW in the same year. In late 2002, the company concluded the sale of Collision Team of America (CTA) and Kwik-Fit.

The introduction of a new method of production: This refers to changing technological relationship or the existing production function. In order to lower the per unit cost of production, an entrepreneur may introduce a new method of production or substitute new and cheaper inputs in place of existing inputs. If an entrepreneur is successful in doing this, she or he will ensure the maximum profit from the sale of a new product. Henry Ford was the first entrepreneur to introduce a new method of production and the tradition continued throughout the history of the company. Ford made several acquisitions during 2005. This included the reacquisition of Visteon's twenty-three North American facilities in order to protect its supply of components. The company also acquired a minority interest in the Beanstalk Group, a majority owned subsidiary that licensed trademarks and subsequently sold 100\% interest in the Beanstalk Group. Ford sold its subsidiary The Hertz during 2005. Ford also sold its interests in Mahindra \& Mahindra and Vastera during the same year. The company also exchanged its 8.3 million shares in Ballard Power Systems for an equity interest in NuCellSys, a 50:50 joint venture with Daimler Chrysler.

The opening of a new market: This is one of the two functions of innovation. Once a product has been developed with the least cost method of production, an entrepreneur looks for a new market. Ford made several acquisitions during 2005. This included the reacquisition of Visteon's twenty-three North American facilities in order to protect its supply of components. The company also acquired a minority interest in the Beanstalk Group, a majority owned subsidiary that licensed trademarks and subsequently sold 100\% interest in the Beanstalk Group. Ford sold its Hertz 
subsidiary during 2005. Ford also sold its interests in Mahindra \& Mahindra and Vastera during the same year. The company also exchanged its 8.3 million shares in Ballard Power Systems for an equity interest in NuCellSys, a 50:50 joint venture with DaimlerChrysler.

The conquest of a new source of supply of a raw material: This is the second function of innovation. Because resources are scarce, new source of supply of raw materials is an important factor in ensuring continuous supply of a newly developed product. Ford expanded its presence in China during 2002 and 2003 ostensibly to acquire new sources of supply of labor at cheaper cost. The Changan Ford (a joint venture operation with Changan Automobile) assembly plant located in Chongqing became operational and production of the Fiesta in China started in mid 2003. The company's Ford Services Thailand became operational later in 2003. Ford sold Cosworth, its motor sport technology engineering company and Jaguar Racing, its Formula One team, during 2004. Also in 2004, the company recalled about 600,000 vehicles of its Escape and Mazda Tribute SUVs. In the same year, the company launched the 2005 F-Series Super Duty and also introduced the Ford Expedition King Ranch.

The carrying out of a new organization of an industry: In describing the innovation as the final process of changing a production function, Schumpeter related this process of innovation to breaking into a monopoly market. In addition to producing and selling cars and trucks, Ford also provides a range of after sales services and products through its dealer network. In addition to the products that are sold to dealers for retail sale, Ford also sells cars and trucks to its dealers for sale to fleet customers, including daily rental car companies, commercial fleet customers, leasing companies and governments. The company provides services such as maintenance and light repair, heavy repair, collision, vehicle accessories and extended service warranty. In North America, the company markets these products and services under several brands, including Genuine Ford and Lincoln-Mercury Parts and Service, Ford Extended Service Plan (ESP) and Motor Craft.Ford made several acquisitions during 2005. This included the reacquisition of Visteon's twenty-three North American facilities in order to protect its supply of components. The company also acquired a minority interest in the Beanstalk Group, a majority owned subsidiary that licensedtrademarks and subsequently sold $100 \%$ interest in the Beanstalk Group. Ford sold its subsidiary The Hertz during 2005. Ford also sold its interests in Mahindra \& Mahindra and Vastera during the same year. The company also exchanged its 8.3 million shares in Ballard Power Systems for an equity interest in NuCellSys, a 50:50 joint venture with DaimlerChrysler.

The financial services division operates through the company subsidiary, Ford Motor Credit (Ford Credit). Ford Credit offers a wide variety of automotive financing products to, and through automotive dealers throughout the world. The predominant share of Ford Credit's business consists of financing Ford vehicles and supporting the company's dealers. Ford Credit's primary financial products fall into three categories: retail financing, wholesale financing, and other financing. In retail financing, Ford engages in purchasing retail installment sale contracts and retail lease contracts from dealers and offering financing to commercial customers - primarily vehicle leasing companies and fleet purchasers - to purchase or lease vehicle fleets. In wholesale financing, Ford offers loans to dealers to finance the purchase of vehicle inventory. In other financing, Ford offers loans to dealers for working capital, improvements of dealership facilities, and for acquiring and refinancing real estate.

\section{SUMMARY AND CONCLUSIONS}

Using the Five-Factor Model of Schumpeter, the paper analyzed entrepreneurship in the U.S. auto industry with particular reference to Ford Motor Company. While two of the Big Three auto makers sought government help and declared bankruptcy in the height of the Great Recession of 2007-2009, the remarkable performance of Ford was noted in neither seeking government help for the TARP fund nor declaring bankruptcy. The paper noted that Ford Motor Company had a history of entrepreneurial tradition dating back to its founder, Henry Ford in a number of areas which the other two auto makers lacked. These practices include technological innovation for cost cutting measures, introduction of new products after significant market research, expansion of market and creation of new economic organization. The tradition of entrepreneurship enabled Ford Motor Company to earn a hefty profit during the Great Recession. 


\section{AUTHOR INFORMATION}

Dr. Wali I. Mondal is a Professor of Business at National University in La Jolla, California where he also served as Interim Dean during 2006-07 and 2007-08 academic years. Mondal received his Ph.D. from the Ohio State University and has been a full time faculty for over 28 years. During 1993-96, he served as the Chair of the Department of Accounting, Economics and Business Education at Henderson State University. He has published a scholarly book, book chapter and over 70 papers in national and international refereed journals. Professor Mondal is the founding President and Conference Chair of the American Society of Business and Behavioral Sciences (ASBBS www.asbbs.org ). He is also the Editor or Editor-in-Chief of 5 national and international journals.

\section{REFERENCES}

1. Arrow, Kenneth J. 1962. "Economic Welfare and the Allocation of Resources for Invention." In The Rate and Direction of Industrial Activity: Economic and Social Factors. National Bureau of Economic Research. Princeton, NJ: Princeton University Press

2. $\quad$ Datamonitor, USA. 2009: New York.

3. Gartner, William B. 1990. "Who Are We Talking About When We Talk About Entrepreneurship?” Journal of Business Ventures, January: 15-28

4. Gladwin, C.H (ed). 1991. Structural Adjustment and African Women Farmers. Gainesville, FL: University of Florida Press.

5. Herbert, R. and A. Link. 1982. The Entrepreneur: Mainstream Views and Radical Critique. New York: Praeger.

6. Lange, O. 1943. “A Note on Innovations.” Review of Economic Statistics, February 1943: 19-25.

7. McDaniel, Bruce. 2002. Entrepreneurship and Innovation: An Economic Approach. Armonk, New York: M.E. Sharpe.

8. Mills, John Stuart. 1848. Principles of Political Economy. London: Macmillan Press.

9. Mulally, Alan. 2008. Testimony before the U.S. Congress; December 4, 2008.

10. Rostow, W.W. 1948. British Economy of the Nineteenth Century. New York: Oxford University Press.

11. Say, J.B. 1821. A Treatise on Political Economy. (Translated by C.R. Princep). Boston: Wells and Lilly (originally published in 1803).

12. Schumpeter, Joseph A. 1950. Capitalism, Socialism and Democracy. New York: Harper and Sons.

13. 1939. Business Cycles: A Theoretical, Historical, and Statistical Analysis of the Capitalist Process. New York: McGraw-Hill.

14. 1936. The Theory of Economic Development: An Inquiry into Profits, Capital Credit, Interest and the Business Cycle. Cambridge, MA: Harvard University Press.

15. Sweezy, P.M. 1943. "Professor Schumpeter's Theory of Innovation". Review of Economic Statistics. February 1943: 93-96.

16. $\quad$ www.datamonitor.com 15 May 2009

17. www.pe.com/business/local/stories/PE_Biz_W_webonly ford29.3555d28.html

18. www.motorintelligence.com

19. www.wsj.com; July 01, 2009

20. http://www.france24.com/en/20100407-gm-posts-billion-dollar-loss-usa-business-automaker-cars-sec

21. http://www.france24.com/en/20100407-gm-posts-billion-dollar-loss-usa-business-automaker-cars-se 


\section{NOTES}

